\title{
The Role of Information Quality on the Performance of Hotel Industry in Kenya
}

\author{
Scholastica Makau \\ Charles Lagat \\ Ronald Bonuke \\ Moi University, Kenya
}

doi: 10.19044/esj.2017.v13n20p169 URL:http://dx.doi.org/10.19044/esj.2017.v13n20p169

\begin{abstract}
In recent years there have been various studies investigating factors that influence hotel performance in Kenya mostly in coastal region. These studies have analyzed the drivers and factors influencing performance focusing at reasons why some hotels perform outstandingly while other do not. This study focused on how information quality affects the hotel performance. Resource base View theory was used in formulating the study framework. The study adopted a survey design which allowed easy sampling and analysis of data. The Target population was employees of 3 to 5 star rated hotels as classified by Hotel and Restaurants Authority (HRA) as its responses, with a sample of 324 from a population of 9,208 employees. SPSS software was used in analyzing and interpreting data that was collected. The sampling technique used was stratified random sampling. Primary data was collected by use of structured questionnaire instrument and a pilot study was conducted to check for the reliability and validity of the research instruments which were administered through drop and pick method. The results showed that firms need to align their supply chain practices with the level of their information quality in order to achieve enhanced overall business performance. Based on these study findings the researcher concluded that Information Quality has a significantly influenced on hotel Performance to very a great extent. In order for hotel managers to sustain their customer and retain the customer base , there is need to take into consideration on the quality and security of information they make available to their customers as well as their potential customers in order to make right decision e.g. on purchase, price, accommodation, service reservations among other services offered in hotels.
\end{abstract}

Keywords: Information quality, quality service, service realibility, timeliness and organizational performance 


\section{Introduction}

Providing excellent and quality information and achieving customer satisfaction in pursuance of performance is the most important and challenging issue facing the contemporary service industry (Hung et al., 2003). There has been a vast amount of studies that empirically investigated the relationship between these concepts, reporting significant influence that information quality exerts on customer satisfaction. However, only few of them examined the information quality dimensions and elements that affect performance in hotel industry.

One of the important questions facing business sector has been why some hotels perform outstandingly well while others fail and this has influenced a study on the drivers of organizational performance, observes (Iravo, Ongori and Munene 2013). Moullin (2007) asserts that performance measurement is one of the tools which accelerate firms in terms of monitoring performance, identifying the areas that need attention, enhancing motivation, improving communication and strengthening accountability. An organization requires adjusting itself to be in line with the changes in order to gain competitive advantage confirms (Donaldson, 2006). It is reasoned that for an organization to be successful it has to record high returns and identify performance drivers from the top to the bottom of the organization. Performance management and improvement is at the heart of strategic management because a lot of strategic thinking is geared towards defining and measuring performance (Nzuve \& Nyaega, 2011).

Hotel services are considered as one of the most important and high customer contact services in the tourism industry (Shahin \& Samea, 2010). Service quality management and improvement are the most critical factors in today's hotels' business. Hotels are intermediaries who bear the responsibility of satisfying customers by providing quality tourism service in terms of quality information to the tourists. It is therefore crucial to develop an understanding of the success of hotel business in the Kenyan context. Besides the numerous studies on the quality management and performance linkages, there is scarcity of empirical and conceptual studies on Kenyan hotels. Specifically, there are inadequate information quality practices and its role on performance studies on hotels operating in Kenya. Performance is affected by a number of factors, all of which should be taken into account when managing, measuring, modifying and rewarding performance (Armstrong \& Baron, 1998). One of the factors is information quality and how this information is managed. There are various concepts in measuring performance, such as sales per employee, export sales, growth rates of sales, total assets, total employment, operation profit ratio, turnover and return on investment (Kemp et al., 2003). Further, according to (Yusuf, 2002), 
alternative measures of performance may be different, depending on the size and type of firm or its ownership.

Information quality is defined an assessment or measure of how fit an information object is for use, (Jason et al.., 2011). So what are the dimensions/factors that comprise information quality and thus lead to its final valuation? (Jason et al.., 2011) affirms that dimensions within this group are accuracy (correct, reliable), believability (regarded as true and credible), objectivity (unbiased) and reputation (trusted in terms of source or content). The contextual quality group advances the discussion and emphasizes that quality cannot be judged without assessing the context at hand. Value-added (provide advantages from use), relevancy (applicable and helpful), timeliness (age of the data is appropriate), completeness (sufficient breadth, depth and scope) and appropriate amount of data (appropriate volume of data available) are therefore identified within this area. The representational quality group focuses on data representation aspects and includes interpretability (appropriate language and units and data definitions are clear), ease of understanding (without ambiguity and easily comprehended), representational consistency (always presented in the same format and are compatible with previous data) and concise representation (compactly represented without being overwhelming) dimensions.

Yang et al. (2002) developed a model, which is useful for deciding what to do to improve information quality (IQ). The model's focus on product or service delivery and on how quality can be assessed by specifications or customer expectations employs quality aspects that are relevant to delivering better quality information. The IQ model focused on accessing timelines, reliability, availability, targeted audience, completeness, confidentiality and integrity of the information. The management in hotel industry like any other can use the feedback on performance to make adjustments to policies and other modes of organizational operations (Wadongo, Odhuno \& Kambona, 2010).

Previous studies on hotel performance cover factors, operation strategies, labor turnover and wastage, influence and drivers affecting hotel performance in Kenya. This means that there are studies on strategic management on hotels (Jane Kemunto Ongori, Dr. Mike Iravo, Dr. Charles Elijah Munene (2013), factors affecting performance of hotels and restaurants in Kenya, operation strategy and performance in the hotel industry ( Ng'ang'a Anne Wangui 2013), assessment of labor turnover and wastage, Kung'u Samson Kuria 2011). Thus, there are studies on strategic management accounting (Collier and Gregory, 1995), the structure of cost accounting system (Brignall et al., 1991; Brignall, 1997), the general and relative importance of the knowledge in accounting techniques in hotel 
management (Damitio and Schmidgall, 1990), effect of Strategic Management Drivers on the performance of the hotel industry (Jean Mutindi Mzera Uzel, 2015).

The majority of hotels use traditional profitability measures for performance evaluation (Mia and Patier, 2001; Atkinson and Brown, 2001; Haktanir and Harris, 2005; Pavlatos and Paggios, 2007). (Jagels \& Ralston, 2007) assert that without management's understanding of the information being provided, management's effectiveness will be greatly reduced. For the hospitality industry business it is necessary the organization of a managerial accounting system to analyze the performance of each department and to decide how to increase the profit and the quality of all services. To achieve this, (Jagels et al., 2007) continues to say that three types of information are necessary: information about costs; information about prices and information about contribution and profit policy. Black and Porter (1996) particularly emphasize that information technologies facilitate the availability of information in enabling the performance assessment systems for continuous improvement. Marchand, Kettinger and Rollins (2000) have recently elaborated the link between IT and firm performance. Based on a large sample survey of global firms, they concluded that three sets of factors explained these firms' continued success with the deployment of IT: (i) the quality of their information technology management practices (e.g., integrating IT into key operational and managerial processes), (ii) their ability to develop appropriate information management processes for sensing, gathering, organizing, and disseminating information, and (iii) their ability to instill desired information behaviors and values (e.g., proactiveness, sharing, integrity).

\section{Research Objective}

The objective of this research was to determine the role of information quality on hotel performance.

\section{Quality Information use and Performance}

There are various definitions for information quality provided by reviewing literature; however, it is the concept of "fitness for use" that is most prevalent. Further, there is an abundance of attributes and dimensions that have been identified in the literature that explain information quality in more measurable terms. According to Gustavsson, M. and Jonsson, P. (2008) the attributes of information quality are complete, concise, reliable, timely valid, accessible, appropriate amount, credible relevant and understandable. Stvilia, B., Gasser, L., Twidale, M.B., Smith, L.C. (2007) assert that for firms' processes that depend on information, the quality of information is one of the key determinants of the quality of their decisions and actions. 
Such view is also shared by others, for example: Najjar (2002) connects IQ to service quality in the banking industry, Miller (2005) links IQ with firm’s market share, Rossin (2007) associates IQ with the performance characteristics of supply chains, whereas Vanden (2008) emphasizes the significance of IQ in determining option prices. While it is broadly recognized that quality information plays a critical role in the success of firms (Choo, 1996; Daft and Lengel, 1986; Porter and Millar, 1985), any information acquired by decision-makers will deliver little impact on firm performance if it is not actually utilized in the making of decisions (Davenport and Beers, 1995; Diamantopoulos and Souchon, 1999).

Researchers increasingly claim that leveraging such performance benefits depends less on possessing the technology and more on the ability to best utilize the information in decision-making processes (Davenport and Beers, 1995; Diamantopoulos and Souchon, 1999; Rindfleisch and Moorman, 2001). Hotel Managers should recognize that employees' intention to use available information for their decision-making and process management activities depends on the quality of available information. They should recognize that employees are more likely to engage in utilizing information when its quality and the quality of the system itself meet employees' information needs, (Xu et al., 2013). This will ensure firm performance since the information is meeting user requirements. Gustavsson, M. and Jonsson, P. (2008) defines information quality as concept of 'fitness for use'.

\section{Information Security and Performance}

The ISO standard 27001 describes information as an asset and an asset as anything that has value in an organization. ISO 2700 is an international Standard and the fundamental aim is to protect information from security threats whether internal or external, deliberate or accidental such as virus attach, misuse, theft, vandalism/terrorism and fire. ISO 27001 quickly produces a return on investment giving thorough guidance on complying with regulations and contractual requirements regarding information security, privacy and IT governance. ISO 27001, an information security standard is an international Standard and the fundamental aim is to protect information from security threats whether internal or external, deliberate or accidental such as virus attach, misuse, theft, vandalism/terrorism and fire. The standards guides the way to manage information security by preserving the confidentiality, integrity and availability (commonly known as C.I.A.) of information assets. In order for organizations to establish this system, there is whole process given in the standard known as risk assessment methodology (RAM). RAM is a 
systematic process of identifying all organizational information assets, valuation of such assets, identification of threats and Vulnerabilities (risks), selection of appropriate controls to identified risks in order to treat them.It gives guidance on the overall information security management, based on a business risk approach, to establish, implement, maintain and continually improve information security. The standards indicate that information is asset and an asset is anything that has value to organization. The controls are appended in the ISO 27001 standard in Annex A which is a normative document and guides the users to identify the controls which have 14 domains i.e. from A.5 - A.18 for application. This standard ensures business continuity in organizations because it safeguards security breaches on information.

\section{Information Quality and Performance}

There are various definitions for information quality provided by reviewing literature; however, it is the concept of "fitness for use" that is most prevalent. This definition takes the perspective of assuring quality based on user needs within organizations and between organizations asserts (Inda, Abu, Rohaizat , Noriza 2014). Further, there is an abundance of attributes and dimensions that have been identified in the literature that explain information quality in more measurable terms. According to the attributes of information quality are complete, concise, reliable, timely valid, accessible, appropriate amount, credible relevant and understandable. Furthermore (Inda et al., 2014) argued that the components of information quality are intrinsic data quality: consists of accuracy, objectivity, believability, and reputation; Contextual data quality: consists of valueadded, relevancy, timeliness, completeness, and appropriate amount of data; Representational data quality: consists of interpretability, ease of understanding, representational consistency, and concise representation; Accessibility data quality: consists of accessibility and access security. Information quality content, Information content, which consists of accurate, complete, concise, useful in daily jobs, and relevant for decision making; and information format, which consists of good appearance and format, consistency, and easy to understand. IQ can be measured by using various variable such as currency, completeness, accuracy, compatibility, and convenience of access to information.

The emerging popularity of Customer Relationship Management (CRM) and many other e-commerce initiatives are creating requirements for large, integrated data repositories and advanced analytical capabilities, (Vanden, J.M., 2008). Consequently, the quality of data in those data repositories has become a greater concern for firms. Poor information quality impacts a typical firm in many ways on the operational, tactical and strategic 
level. These impacts include customer dissatisfaction, increased operational costs, less effective or wrong decision-making, and a reduced ability to make and execute strategies adds (Vanden, J.M. 2008). Furthermore, poor information quality reduces the employees' trust in the data, the employees' enthusiasm to use the data, and makes it more difficult to align the firm (Rai, Patnayakuni \& N. Patnayakun 1997). Poor information quality and its underlying causes are potent contributors to an "information ecology" inappropriate for the Information Age, (Davenport 1997).

Companies today are repeatedly recognizing that making quality decisions depends upon the quality of information available to support these decisions (Ge \& Helfert, 2008), thus making the provision of quality information the key to gaining a competitive advantage (Salaun \& Flores, 2001). Nevertheless, simply acquiring or possessing information is not directly related to company's performance, but it is rather the utilization of information that is the key link between information acquisition and the company's performance (Souchon \& Diamantopoulos, 1996). If companies want the available quality information to contribute to their performance, such information must be used to improve their decision-making (Raghunathan, 1999).

In today's business environment quality information is a matter of primary interest. For more and more companies, information has increasingly become a critical resource and an asset in their business processes (Kirk, 1999). According to Stvilia, Gasser, Twidale, \& Smith (2007), for companies' processes that depend on information, the quality of information is one of the key determinants of the quality of their decisions and actions. The contribution of high-quality in-formation to companies is that it makes it easier to convert available information into knowledge, by helping to interpret and evaluate the information, by assisting the connection with prior knowledge, and by facilitating the application of the information to new contexts (Eppler \& Wittig, 2000).

\section{Research Methodology}

This research employed a survey to obtain data measuring participants' perceptions of information quality in the hotel performance. The self administered questionnaires were used to collect data between February and April 2016. The research was carried out in Nairobi, largest city and capital city of Kenya which houses the majority of rated hotels. Explanatory research designs were utilized in this study. The target population comprised of 3 - 5 star hotels with a total of 9,208 staff in Nairobi County. One hundred and eighty six (186) responses were obtained out of an anticipated maximum number of two hundred and forty six (246) translating 
to $75.61 \%$ approx $76 \%$. A questionnaire instrument was used to collect the data. The researchers observed confidentiality of respondents by ensuring that ethical procedures were adhered to.

In order to assess information quality we adopted previously used and validated indicators provided by Jason et al., (2011). The questionnaire used was structured questionnaire with 5-point Likert scales and 15 of the information quality criteria items were used. The performance of the hotels was measured by the level of business performance. Data collected was analyzed by use of descriptive and inferential statistics.

\section{Study results and findings}

\section{Reliability test on the moderating variable, IQ and Hotel Performance}

Reliability was measured using Cronbach's Alpha coefficient which was used to measure the internal consistency of the research instrument. The Cronbach's alpha coefficient ranges between 0 and 1 and an alpha coefficient of a minimum of 0.70 is considered appropriate. The variables were found to be highly reliable with an alpha coefficient greater than the minimum accepted Cronbach's alpha coefficient of 0.70 (Hair et al., 2010). The results were summarized in Table 1

Table 1: Reliability Check on the moderating variable, IQ

\begin{tabular}{|c|c|c|}
\hline \multicolumn{3}{|c|}{ Reliability Statistics } \\
\hline Variable & Cronbach's Alpha & N of Items \\
\hline Information Quality & .925 & 15 \\
\hline Hotel Performance & 807 & 6 \\
\hline
\end{tabular}

\section{Descriptive Statistics}

From Table 2 and 3 all the factors on both variables attained mean scores of above 3.5 implying that most respondents on average agreed with statements on the variables. These findings further concur with the study carried by Gustavsson, M. and Jonsson, P. (2008) that the attributes of information quality are complete, concise, reliable, timely valid, accessible, appropriate amount, credible relevant and understandable make information 'fit' for use.

Stvilia, B., Gasser, L., Twidale, M.B., Smith, L.C. (2007) assert that for firms' processes that depend on quality of information makes the best decision since its one of the key determinants of the quality of decisions and actions they make. Such view is also shared by others, for example: Najjar (2002) connects IQ to service quality in the banking industry, Miller (2005) links IQ with firm's market share, Rossin (2007) associates IQ with the performance characteristics of supply chains, whereas Vanden (2008) emphasizes the significance of IQ in determining option prices. (Choo, 1996; Daft and Lengel, 1986; Porter and Millar, 1985) assert that any information acquired by decision-makers will deliver little impact on firm performance if 
it is not actually utilized in the making of decisions. This confirms the fact that a mean of over 3.5 agreed on tested variable on information quality.

Table 2: Descriptive Statistics of Information Quality

\begin{tabular}{|c|c|c|c|c|c|c|}
\hline \multirow{2}{*}{} & Mean & $\begin{array}{c}\text { Std. } \\
\text { Deviation }\end{array}$ & \multicolumn{2}{c|}{ Skewness } & \multicolumn{2}{c|}{ Kurtosis } \\
\cline { 2 - 7 } & Statistic & Statistic & Statistic & Std. Error & Statistic & $\begin{array}{c}\text { Std. } \\
\text { Error }\end{array}$ \\
\hline Accessibility & 3.64 & 1.021 & -.635 & .135 & .003 & .270 \\
\hline Appropriate amount & 3.45 & 1.138 & -.411 & .135 & -.621 & .270 \\
\hline Believability & 3.53 & 1.212 & -.455 & .135 & -.711 & .270 \\
\hline Completeness & 3.57 & 1.118 & -.688 & .135 & -.177 & .270 \\
\hline Concise & 3.77 & .970 & -.763 & .135 & .381 & .270 \\
\hline Consistent & 3.76 & .994 & -.624 & .135 & -.082 & .270 \\
\hline Representation & 3.80 & .918 & -.680 & .135 & .386 & .270 \\
\hline Ease of operation & 3.76 & 1.003 & -.807 & .135 & .367 & .270 \\
\hline Free-of-error & 3.69 & .981 & -.604 & .135 & .163 & .270 \\
\hline Interpretability & 3.72 & .976 & -.539 & .135 & -.087 & .270 \\
\hline Objectivity & 3.67 & 1.129 & -.804 & .135 & -.009 & .270 \\
\hline Relevancy & 4.02 & .892 & -.965 & .135 & 1.038 & .270 \\
\hline Security & 4.03 & .963 & -1.066 & .135 & 1.017 & .270 \\
\hline Timeliness & 3.99 & .957 & -.892 & .135 & .516 & .270 \\
\hline Understandability & 4.09 & .916 & -.913 & .135 & .549 & .270 \\
\hline \multicolumn{7}{|c|}{$N=324$} \\
\hline
\end{tabular}

Table 3: Descriptive statistics on the dependent variable

\begin{tabular}{|c|c|c|c|c|c|c|}
\hline & Mean & $\begin{array}{c}\text { Std. } \\
\text { Deviation }\end{array}$ & \multicolumn{2}{|c|}{ Skewness } & \multicolumn{2}{c|}{ Kurtosis } \\
\cline { 2 - 7 } & Statistic & Statistic & Statistic & $\begin{array}{c}\text { Std. } \\
\text { Error }\end{array}$ & Statistic & $\begin{array}{c}\text { Std. } \\
\text { Error }\end{array}$ \\
\hline $\begin{array}{c}\text { We have bought new } \\
\text { products and services to } \\
\text { the market faster than } \\
\text { our competitors. }\end{array}$ & 3.59 & 1.008 & -.556 & .135 & -.095 & .270 \\
\hline $\begin{array}{c}\text { The success rates of our } \\
\text { new products and } \\
\text { services have been very } \\
\text { high. }\end{array}$ & 3.64 & 1.099 & -.632 & .135 & -.274 & .270 \\
\hline $\begin{array}{c}\text { Our productivity has } \\
\text { exceeded that of our } \\
\text { competitors. }\end{array}$ & 3.67 & .979 & -.513 & .135 & -.330 & .270 \\
\hline $\begin{array}{c}\text { Our profit has exceeded } \\
\text { that of our competitors. }\end{array}$ & 3.43 & 1.089 & -.503 & .135 & -.371 & .270 \\
\hline $\begin{array}{c}\text { Our financial } \\
\text { performance has been } \\
\text { outstanding. }\end{array}$ & 3.66 & .958 & -.592 & .135 & -.091 & .270 \\
\hline
\end{tabular}




\begin{tabular}{|c|c|c|c|c|c|c|}
\hline $\begin{array}{c}\text { Our financial } \\
\text { performance has } \\
\text { exceeded that of our } \\
\text { competitors. }\end{array}$ & 3.67 & 1.050 & -.673 & .135 & -.044 & .270 \\
\hline$N=324$ & \multicolumn{1}{|l|}{} & & & & \\
\hline
\end{tabular}

\section{Performance against IQ}

\section{Correlation analysis of IQ and performance}

The study sought to establish whether there was correlation between hotel Performance and Information Quality. The findings were summarized in Table 4. From the table, a positive correlation coefficient existed between hotel performance and Information Quality.

Table 4: Correlation coefficient between IS Planning and Firm Performance

\begin{tabular}{|c|c|c|}
\hline \multicolumn{3}{|c|}{ Correlations } \\
\hline & Firm Performance & Information Quality \\
\hline Firm Performance & 1 & $.464^{* *}$ \\
\hline Information Quality & $.464^{* *}$ & 1 \\
\hline \multicolumn{2}{|c|}{ Pearson Correlation Sig. (2-tailed) $=.000$} \\
\hline \multicolumn{2}{|c|}{$\mathrm{N}=324$} \\
\hline \multirow{2}{*}{$* *$ Correlation is significant at the 0.01 level (2-tailed). }
\end{tabular}

\section{Line of Best Fit of performance and IQ}

The study sought to find out if linear relationship existed between Information Quality and Firm Performance. Therefore, a curvilinear graph was generated from the data using SPSS Software. The findings were summarized in Figure1. From the figure, there is an observed positive linear relationship between Information Quality and Performance as most of the scatter dots lie close or within the line of best fit.

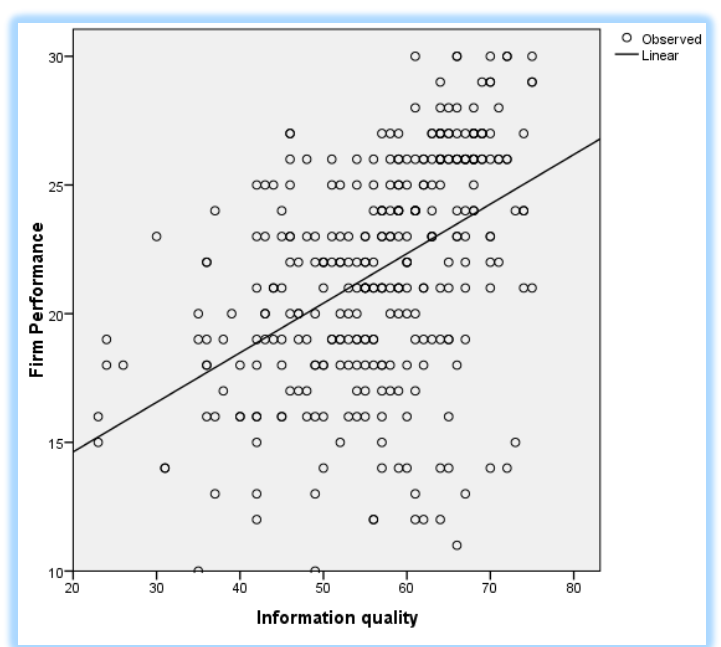

Figure 1: Curvillinear Graph showing a linear relationship between Information Quality and Hotel Performance 


\section{Linear regression analysis of performance and IQ}

A regression analysis was carried out to investigate the extent of influence that Information Quality had on Firm Performance. The Model Summary Table 5 shows that $21.3 \%$ (Adjusted R Square $=.213$ ) of the total variability in the dependent variable (Firm Performance) can be explained by Information Quality.

Table 5: Model Summary Table of Information Quality and Firm Performance

\begin{tabular}{|c|c|c|c|c|}
\hline \multicolumn{5}{|c|}{ Model Summary } \\
\hline Model & $\mathrm{R}$ & $\mathrm{R}$ Square & Adjusted R Square & $\begin{array}{c}\text { Std. Error of the } \\
\text { Estimate }\end{array}$ \\
\hline 1 & $.464^{\mathrm{a}}$ & .215 & .213 & 3.920 \\
\hline \multicolumn{5}{|c|}{ a. Predictors: (Constant), Information quality } \\
\hline
\end{tabular}

From the Anova Table 6, the regression model is statistically significant as p-value was less than .05 threshold at Sig. $=.000$. In addition, the null hypothesis that Information Quality does not have a statistically significant influence on Firm Performance is rejected and the alternative hypothesis that Information Quality has a statistically significant influence on Firm Performance is accepted.

Table 6. Anova Table of Information Quality and Firm Performance

\begin{tabular}{|c|c|c|c|c|c|c|}
\hline \multicolumn{7}{|c|}{ ANOVA $^{\mathrm{a}}$} \\
\hline \multirow{2}{*}{1} & Model & Sum of Squares & $\mathrm{df}$ & Mean Square & $\mathrm{F}$ & Sig. $^{\mathrm{N}}$ \\
\cline { 2 - 8 } & Regression & 1358.635 & 1 & 1358.635 & 88.410 & $.000^{\mathrm{b}}$ \\
\cline { 2 - 7 } & Residual & 4948.337 & 322 & 15.368 & & \\
\hline & Total & 6306.972 & 323 & & & \\
\hline \multicolumn{7}{|c|}{ a. Dependent Variable: Firm Performance } \\
\hline
\end{tabular}

The Coefficient Table 7 shows that Information Quality contributes a statistically significant value of .193 for every unit change in the dependent variable (Performance).

Table 7: Coefficients Table of Information Quality and Firm Performance

\begin{tabular}{|c|c|c|c|c|c|c|}
\hline \multicolumn{7}{|c|}{ Coefficients $^{\mathrm{a}}$} \\
\hline \multirow{2}{*}{\multicolumn{2}{|c|}{ Model }} & \multicolumn{2}{|c|}{$\begin{array}{l}\text { Unstandardized } \\
\text { Coefficients }\end{array}$} & \multirow{3}{*}{$\begin{array}{c}\text { Standardized } \\
\text { Coefficients } \\
\text { Beta } \\
\end{array}$} & \multirow{3}{*}{$\frac{\mathrm{t}}{9.159}$} & \multirow{3}{*}{$\frac{\text { Sig. }}{.000}$} \\
\hline & & $\mathrm{B}$ & Std. Error & & & \\
\hline \multirow[t]{2}{*}{1} & (Constant) & 10.781 & 1.177 & & & \\
\hline & $\begin{array}{c}\text { Information } \\
\text { quality }\end{array}$ & .193 & .020 & .464 & 9.403 & .000 \\
\hline
\end{tabular}

\section{Multiple Linear Regression Analysis Firm Performance and Information Quality}

A regression analysis was carried out to investigate for the extent of contribution of factors on Information Quality to Firm Performance. The 
Model Summary Table 8 shows that $24.3 \%$ (Adjusted R Square $=.243$ ) of the total variability in the dependent variable (Firm Performance) can be explained by factors on Information Quality.

Table 8: Model Summary Table of Information Quality and Firm Performance Model Summary

\begin{tabular}{|c|c|c|c|c|}
\hline Model & $\mathrm{R}$ & R Square & Adjusted R Square & $\begin{array}{c}\text { Std. Error of the } \\
\text { Estimate }\end{array}$ \\
\hline 1 & $.527^{\mathrm{a}}$ & .278 & .243 & .64050 \\
\hline
\end{tabular}

a. Predictors: (Constant), Understandability, Accessibility , Free-of-error, Ease of operation,

Objectivity, Relevancy, Representation, Concise, Completeness, Security, Timeliness, Interpretability, Consistent, Appropriate amount, Believability

From the Anova Table 9, the regression model is statistically significant as p-value was less than .05 threshold at Sig. $=.000$. In addition, the null hypothesis that Information Quality does not have a statistically significant influence on Firm Performance is rejected and the alternative hypothesis that Information Quality has a statistically significant influence on Firm Performance is accepted.

Table 9: Anova Table of Information Quality Factors and Firm Performance ANOVA $^{\mathrm{a}}$

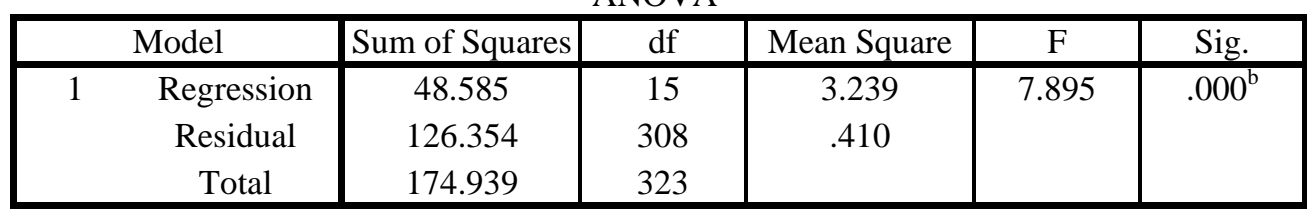

a. Dependent Variable: Firm Performance

b. Predictors: (Constant), Understandability, Accessibility , Free-of-error, Ease of operation, Objectivity, Relevancy, Representation, Concise, Completeness, Security, Timeliness, Interpretability, Consistent, Appropriate amount, Believability

From the Coefficient Table 10 shows that Accessibility, Consistent, and Free-of-error factors contributes statistically significant values of .124, 119 and -.156 respectively, for every unit change in the dependent variable (Performance). 
Table 10: Coefficient Table of Information Quality Factors and Firm Performance Coefficients

\begin{tabular}{|c|c|c|c|c|c|}
\hline \multirow{2}{*}{ Model } & \multicolumn{2}{|c|}{$\begin{array}{c}\text { Unstandardized } \\
\text { Coefficients }\end{array}$} & $\begin{array}{c}\text { Standardized } \\
\text { Coefficients }\end{array}$ & & \\
\cline { 2 - 4 } & B & Std. Error & Beta & $\mathrm{t}$ & Sig. \\
\hline (Constant) & 1.958 & .212 & & 9.234 & .000 \\
Accessibility & .124 & .053 & .173 & 2.335 & .020 \\
& -.031 & .055 & -.049 & -.567 & .571 \\
Appropriate amount & .000 & .057 & -.001 & -.008 & .994 \\
Believability & .040 & .053 & .061 & .755 & .451 \\
Completeness & .010 & .051 & .013 & .195 & .846 \\
Concise & .119 & .057 & .161 & 2.106 & .036 \\
Consistent & .034 & .055 & .042 & .621 & .535 \\
Representation & .090 & .052 & .122 & 1.722 & .086 \\
Ease of operation & -.156 & .046 & -.208 & -3.418 & .001 \\
Free-of-error & .034 & .055 & .046 & .620 & .535 \\
Interpretability & .074 & .044 & .113 & 1.677 & .094 \\
Objectivity &. .038 & .058 & -.045 & -.643 & .521 \\
Relevancy & .037 & .055 & .048 & .666 & .506 \\
Security & .031 & .055 & .040 & .564 & .573 \\
Timeliness & .066 & .056 & .082 & 1.183 & .238 \\
\hline
\end{tabular}

a. Dependent Variable: Firm Performance

\section{Summary of results and findings}

The researcher sought to find the influence of Information Quality on Performance. A curvilinear graph showed that a positive linear relationship existed between Information Quality and Hotel Performance. Information Quality and Hotel Performance had a positive correlation coefficient of .464. A regression analysis between Information Quality and Firm Performance showed that $21.3 \%$ of the total variability in the dependent variable (Firm Performance) can be explained by Information Quality. Anova indicated that, the regression model was statistically significant as p-value was less than .05 threshold at Sig. $=.000$. In addition, the null hypothesis that Information Quality did not have a statistically significant influence on Hotel Performance was rejected and the alternative hypothesis that Information Quality had a statistically significant influence on Hotel Performance was accepted. The beta Coefficients shows that Information Quality contributes a statistically significant value of .193 for every unit change in the dependent variable (Hotel Performance).

\section{Conclusion}

Based on the findings above, this study draws two main conclusions can be made. First, hotel performance depends on information quality very 
much. Secondly and in addition, it was found that information quality and performance have correlation. A regression analysis between Information Quality and Firm Performance showed that the dependent variable (Firm Performance) could be explained by Information Quality. Also, the findings revealed that Information Quality and Firm Performance had a positive correlation coefficient of .464. Based on these study findings the researcher concluded that Information Quality significantly influenced Firm Performance to very great extent. In a similar study Hitt and Brynjolfsson (1996) found that some firms were obtaining significant competitive advantages while others were not. The reason firms did not obtain competitive advantages could be because their information systems did not work effectively and efficiently to produce high quality information to help their business operations or influence consumer behaviors in a positive way. In other words, their information systems were not as well managed and utilized as they should be, or maybe their expensive information systems were processing and producing the data with high rates of errors so that there was not much useful output from which the firm could benefit. Therefore, it is important that firms frequently test and retest the kind of information generated by their information systems to ensure that it is free of errors and useful to the consumers.

\section{Recommendations}

The findings confirmed a study by Zhilin et al. (2005) that Information Quality is defined in terms of the kind of information it avails to the customer i.e. Accurate information, Up-to-date information, Customized information presentation, Valuable tips on products/services, Reliable professional opinions, In-depth market analysis and Unique content. Based on this findings and conclusion that Information Quality significantly influenced hotel Performance, firms must follow the dimensions articulated in Zhilin et al. (2005) when organizing and evaluating the information they avail to their customers.

This study therefore, makes both policy recommendations and gives directions for future research in this area. On policy, the study recommends that hotels needs to implement Information Security management System (ISMS) which will ensure preservation of confidentiality, Integrity and Availability (C.I.A ) of information to enhance information security through the efforts of Ministry of information, Communications and Technology and that of Kenyan Standards Body i.e. Kenya Bureau of Standards (KEBS). In addition, the hoteliers need to undergo awareness training to pass knowledge on the kind of information they should use for their customers. In conclusion, the authors suggest that hotels managers should take a more proactive role to information quality. This is qualified in 
the study because while carrying out this study it was noted that that hotels information in terms of accessibility, consistent and free of error contributed significantly to values of 124,119 and -156 respectively. Implementation of such information mechanisms could go a long way in elevating both the national and international service quality levels and competitiveness. Perhaps future studies will consider the use of longitudinal data which would reveal the dynamic of this phenomenon over an extended period of time.

\section{References:}

1. Aleš \& Andreja (2012), Exploring the Impact of Decision Making Culture on the Information Quality - Information Use Relationship, University of Ljubljana, Slovenia and University, Cardiff, UK

2. Black, S.A., and Porter, L.J. "Identification of critical factors of TQM," Decision Sciences (27:1) 1996, pp 1-15.Davenport, T. H., Information Ecology. Oxford University Press, New York, 1997.

3. Davenport, T.H., Harris, J.G., Morison, R. (2010) Analytics at Work: Smarter Decisions, Better Results. Harvard Business School Publishing, Boston, Massachusetts.

4. Eric Verheul 2011), practical implementation of ISO 27001 Security in organizations Hung, Y.H., Huang, M.L. and Chen, K.S. (2003), Service quality evaluation by service quality

5. Inda Sukati*, Abu Bakar Hamid, Rohaizat Baharun, Noriza Mohd, (2014)Jamal The Moderating Role of Market, Firm and Supply Chain Factors on the Relationship between Information Technology

6. Iravo, M., Ongori, J. \& Munene, C. (2013). Factors affecting the performance of hotels and restaurants in

7. Kenya. A case of Kisii Practices and Supply Chain Agility ISO 27001:2013 Standard - Information Security Management Systems (ISMS)

8. Jason R. C. Nurse, Syed S. Rahman, Sadie Creese, Michael Goldsmith, Koen Lamberts (2011) Information Quality and Trustworthiness: A Topical State-of-the-Art Review University of Warwick, Coventry, CV4 7AL, UK

9. Gustavsson, M. and Jonsson, P. (2008) Perceived Quality Deficiencies of Demand Information and Their Consequences. International Journal of Logistics: Research \& Applications, 11, 295-312.

10. Marchand, D.A., Kettinger, W.J., and Rollins, J.D. "Information orientation: People, technology and the bottom line," Sloan Management Review (41:4) 2000, pp 69-80. 
11. Miller, H. (2005) Information quality and market share in electronic commerce. The Journal of Services Marketing 19, 93-102.

12. Odhuon, L., Kambona, O., Othuno, E. \& Wadongo, B. (2010). Key performance indicators in the Kenyan hospitality industry. A Managerial perspective. Benchmarking, An International Journal, 17 (6), 858-875.performance matrix”, Total Quality Management and Business Excellence, Vol. 14, No.1,pp. 79-89.

13. Rai, A., R. Patnayakuni and N. Patnayakuni, Technology investment and Business Performance. Communications of the ACM, 40(7) 1997, pp.89-97.Rossin, D.F. (2007) An Exploratory Analysis of Information Quality in Supply Chains: Efficient and Responsive Models. Journal of Global Business Issues 1, 151-158.

14. Shahin A. \& Samea M (2010); Developing the Models of Service Quality Gaps: A Critical Discussion.

15. Stvilia, B., Gasser, L., Twidale, M.B., Smith, L.C. (2007) A framework for information quality assessment. Journal of the American Society for Information Science and Technology 58, 17201733.

16. Vanden, J.M. (2008) Information Quality and Options. The Review of Financial Studies 21, 2635-2676.Wixom, Barbara H. and H. J. Watson, An Empirical Investigation of the Factors Affecting Data Warehousing Success. MIS Quarterly, 25(1) 2001, pp.17-41.

17. Hitt, L. and Brynjolfsson, E. (1996). Productivity, Business Profitability and Consumer Surplus: Three Different Measures of Information Technology Value, MIS Quarterly 20(2), pp.121-142. 